\title{
Financial Development and Economic Growth in SSA: A Panel Econometric Approach
}

\author{
Mobolaji Hakeem ${ }^{1} \&$ Oluwatoyin Oluitan, ${ }^{2, *}$ \\ ${ }^{1}$ Department of Economics, University of Ilorin, Nigeria \\ ${ }^{2}$ Department of Accounting \& Finance, Lagos State University, Nigeria \\ *Corresponding author: Department of Accounting \& Finance, Lagos State University, \\ Nigeria E-mail: roselinetoyin@yahoo.com
}

Received: March 9, 2013 Accepted: May 6, 2013 Published: June 6, 2013

doi:10.5296/rae.v5i2.1492 URL: http://dx.doi.org/10.5296/rae.v5i2.1492

\begin{abstract}
In this study, we examine the long run relationship between financial development and economic growth in 24 Sub-Saharan countries in Africa. The study explores the spatial impact in explaining the relationship. We examine the stationarity and weak exogeneity of the variables in the cointegrating vector to determine the causal relationship. The paper supports literature with evidences suggesting a causal relationship between finance and growth as we reject the null hypothesis of no cointegration relationship among the variables for all the different financial development indicators used.
\end{abstract}

Keywords: financial development; economic growth; Sub-Saharan Africa 


\section{Introduction}

Over the last three decades, theoretical and empirical inquiry about the nexus between finance and growth has had a considerable attention in the literature. This relationship has attracted several empirical researches with contrasting conclusion. While some have robust statistical evidence for uni-directional causality from financial development to growth (Gupta, 1984; Jung, 1986; King and Levine, 1993), others have evidence for reverse causation from economic growth to financial development Demetriades and Hussein (1996), others like Calderon and Liu (2003) report bi-directional causality, yet some suggest no evidence of causality. Some justify the use of time series (Gupta 1984, Jung 1986) while others favour cross-section analysis (King and Levine 1993). This study however tries to assess the causality between financial development and growth in a panel data framework.

Patrick (1966) made a succinctly clear distinction between the directions of causality by referring to the causality from financial development to economic growth as supply-leading hypothesis, while causality from the economic growth to financial development was referred to as demand -following. Till date, the validity of these hypotheses are receiving contradicting empirical evidence. For review of recent work on the issue see (Demirguc-Kunt and Levine, 2008).

A cursory look at the pre-1970 or early work in the field reveals that while Bagehot (1873), Schumpeter (1911), and Mckinnon (1973) seem to find empirical support for the supply-leading hypothesis, Robinson (1952), and Goldsmith (1969) find justification for the demand-following proposition. Others have shown evidence of bi-directional causality between economic growth and financial development.

The Post -1970 or recent works also reveal conflicting findings. While King and Levine (1993) find empirical support for the supply-leading hypothesis, Demetriades and Hussein (1996), seem to support the demand-following hypothesis .Calderon and Liu (2003) find empirical support for bi-directional causality. Some pioneers of development economists (Meier and Seers, 1984, Lucas 1988) dismiss finance as having any significant impact on growth (Levine 2004) while some recent researches proffer similar results (Dabos \& Gantman, 2010). In fact, Lucas (1988) considers the relationship as being over-stressed, yet others like Merton (1987) strongly argue that financial development leads to economic growth. Recent empirical investigations still find credence in this postulation (Estrada et al, 2010; Akinlo and Egbetunde, 2010; Johannes et al, 2011). This suggests that the issue is inconclusive in the literature and any study in this regard would further clarify our understanding of the relationship between the two, enhance the formulation of optimal policy and direct the priority of policy makers on financial sector reforms.

The theoretical basis of the relationship between the two suggests that financial instruments, markets and institutions reduce information, enforcement and transaction costs. Financial system influences saving rates, investment decisions, and technological innovation and long run growth rates.

Earlier studies that analyse the relationship between finance and growth have been mostly time 
series and cross section studies. Though, cross sectional studies provide useful insights into the relationship, they have been criticised in a number of ways which include the following: that it is difficult to generalise the findings from such studies since the nature and operation of financial institutions and policies pursued in each country differ (Arestis and Demetriades, 1997; Demetriades and Andrianova 2004). They inadequately account for the complexity of the financial environments and economic histories of each individual country (Ang, 2008). The time series also has been criticised to be only country specific, limited predictive ability and difficult to generalise.

These weaknesses are addressed in a panel data framework study where the individual country specific characteristics are observed. Baltagi (2008) identifies a number of advantages of panel study over time series or cross-sectional studies; these include ability to control for individual heterogeneity. Panel studies are able to control for state and time-invariant variables whereas time series or cross-section study cannot. It gives more informative data, more variability, less collinearity among variables, more degree of freedom and more efficiency. Panel study is better to study the dynamics of adjustment; they can shed light on the speed of adjustments to economic policy changes (Deaton 1995). Harris and Sollis (2003) observe that one of the advantages of panel data within the context of non-stationary data and cointegration analysis is that adding the cross-sectional dimension to time series dimension means that non-stationarity from the time series can be dealt with and combined with the increased data and power that the cross section brings. The latter acts as repeated draws from the same distribution, and thus while it is known that the standard DF type tests lack power in distinguishing the unit root null from stationarity alternatives, the cross - sectional dimension of panel data increases the power of the unit root tests. Furthermore, as $\mathrm{N}$ and $\mathrm{T}$ get large, panel test statistics and estimators converge to normally distributed random variables. This makes testing and inference simpler, and leads to a stronger overall signal than the time series estimator.

This paper contributes to the literature by empirically assessing the relationship between financial development and economic growth in SSA, using panel approach. In particular, it tries to analyse the long run impact of spatial variable in the finance-growth nexus with the view to providing policy makers with the necessary information on the relative impact of this spatial proximity on the financial development in the region in particular and economic growth in general. It is hoped that this analysis, would enhance our understanding of the impact of spatial proximity in the evolution of financial development and economic growth in the region. Finally, it further adds to the empirical literature about the direction of causality between financial development and economic growth in SSA.

The study is divided into six sections with section two discussing the conceptual framework for the study, section three presents financial development and economic growth in SSA, section four discusses the methodology, section five has policy implication and conclusion in the sixth section.

\subsection{Review of Earlier Empirical Studies in SSA}

With Patrick's (1966) hypothesis, it is possible to observe that economic development may actually induce financial growth. Saint Marc (1972) observes that the rich West African 
Economic and Monetary Union (WAEMU) countries also have high financial deepening ratios. Spears (1992) reports high correlation between financial deepening and growth in 9 of the 10 countries studied. Thus they conclude some forms of causality between the two.

King and Levine (1993) while using liquid liabilities as a financial development indicator finds financial sector impacting positively on the economic growth. De Gregorio and Guidotti (1995) using ratio of bank credit to the private sector to GDP as an index of financial development, finds positive and significant effect of financial sector on economic growth, even in low income countries. However on many SSA countries, the results were ambiguous.

Savvides (1995) using a sample of 28 African countries, find positive impact of financial sector on growth only when they control for political freedom in the region. Odedokun (1996) in a panel of 71 countries, including 21 SSA countries, find a positive and significant effect of financial sector on economic growth when using ratio of liquid assets to GDP. Joseph et al (1998), showed Granger causality from financial development to economic growth in 5 SSA countries (Benin, Cameroon, Cote d' Ivorie, Mali and Senegal), and reverse causality in 2 SSA countries (Burkina Faso, and Togo).

Venet and Hurlin (2001) using both ratio of broad money and credit to the private sector to GDP as financial development indicators, in a balanced panel study observe for 16 SSA countries (1968-1998) find that financial sector Granger causes economic growth in seven countries (Cameroon, Gabon, Niger, Burkina Faso, Cote d'Ivorie, Togo and Nigeria). In the other nine countries, they find that it is the economic growth that induces financial development, supporting the demand -following hypothesis suggesting that a decrease in economic growth could retard financial development by inducing massive withdrawal from the banking system for consumption smoothing.

In a panel data framework, they proposed an extension of the Granger causality definition to panel data. For the two indicators used, they find empirical support for uni-directional causality from the economic growth to the financial sector, supporting the Patrick's demand following hypothesis. The results show a heterogeneous causality from financial sector to economic growth in only seven countries, but the causality from economic growth to financial sector is found to be homogenous. They conclude that economic activity drives financial sector development in the region.

In summary, the existing empirical works summarily suggest four types of relationship between financial development and growth depending on the econometric estimation technique used, data frequency and region studied. These relationships are finance causing growth, growth causing financial development, bi- directional causality and no causality. However, $\mathrm{Xu}$ (2000) in a multivariate VAR model study of 41 countries finds that the long run effect of financial development on growth is negative, 14 of his sample countries are in SSA. One of the striking findings in the work of Calderon and Liu (2003) is that though financial deepening and ratio of credit to the private sector have impact on growth, financial deepening has more impact on growth in developing countries. They also find bi causality between growth and finance. 


\subsection{Spatial Externality and Financial Development}

Different studies have identified a number of channels by which financial development relates to growth. Mckinnon (1973) identifies investment outlet, Greenwood and Jovanovic (1990) suggest information, Bencivenga and Smith (1991) explores the channel of technology in the relationship between the two. Patrick (1966) stressed the importance of stages of development in the relationship between finance and growth. He observes that at the early stage of economic development finance causes growth, the creation of new financial services enhances intermediation, savings and investment and leads to higher growth (Supply leading hypothesis). At later development stage, economic growth demands for more financial services, hence, growth leads to financial development (demand-following hypothesis), Demetriades and Law (2006), emphasise the role of institutional factors in the relationship, they observe that in developing countries, openness without institutional quality inhibits financial development, and thus growth leads and finance follows. Whereas in developed but open countries, institutional quality enhances financial development and thus finance leads to growth. This study tries to explore the spatial impact in explaining the relationship between finance and growth.

Market frictions exist that inhibit the role of financial development in growth dynamics. These frictions in terms of laws, institutions, regulations, and policies differ across space and over time. This tends to explain why some countries are more financially developed than others. Financial development influences resource allocation to enhance growth and productivity across time and space (Merton and Bodie, 1995). Hence, Levine (2004) suggests we need theories that describe how financial development influences resource allocation, a vacuum this study tries to fill. This study also tries to assess the role of spatial externality in the relationship between finance and growth. This is particularly useful in building a framework for regional cooperation and economic union.

The waves of globalisation through technological advances and ease in transportation and communication have transformed the financial sectors in many economies by quickening financial innovation, transmission of information and reduction of transaction cost. This trend is further strengthened by a policy regime that lays strong emphasis on liberalisation and openness.

Globalization affects domestic financial markets and enhances financial development by increasing access to capital and lowering cost of capital for productive investments. Mishikin (2007) also highlights the indirect effect of globalization on financial development which includes promotion of reforms and healthy competition, evolution of best practices in the industry, and enhancement of manpower development (Kose et al 2006). Spatial externality may be a viable channel for actualising these potential benefits in an era of globalisation, especially as the region has not significantly benefited from globalization (See Ajayi, 2003, Mobolaji 2008a)

There is also an indirect effect of spatial externality on financial development. The increased interconnectedness among countries suggests that country whose neighbour has high financial development, would also be forced to take necessary steps or build necessary institutions, 
policies and regulations to either improve its level of financial development or initiate policies to embark on financial development. With high capital mobility in the world, a financially underdeveloped country stands the risk of losing potential investment to a more financially developed neighbour. This exerts additional pressure on the host country to implement right policies towards financial development.

High interest rate differentials among countries translate to high differences in cost of capital with its attendant effect on investment and growth in the economy. This creates a competitive environment among countries and consequently may lead to implementing right policies for financial development or risk the potential loss of both domestic and foreign investments to the more financially developed neighbouring countries.

Also, another transmission mechanism of financial development with spatial consideration is that member countries of regional blocs or economic unions, stand to benefit from financial development of other member countries through risk sharing, sharing of records, transmitting of best practices among countries, and thus this can further accentuate regional development.

Another channel is through trade, Rajan and Zingales (2003) observe that simultaneous opening of trade and financial sector is important for financial development. However Mishkin (2007) shows that openness, developed financial sector and good institutions dictate where foreign capital finally resides. Thus, an open country with good institution and strong financial development is likely to attract foreign capital than a neighbouring country with weak financial sector. However, a close country neither attracts foreign capital nor have financial reforms to enhance financial development; hence openness is important in the spatial consideration of financial development.

Finally, this paper contributes to the literature on finance by providing a regional framework for understanding the relationship between finance and growth.

\section{Methodology}

The initial step starts with the panel unit root, followed by a VAR and test for cointegration. This was followed by testing for the weak exogeneity of each of the variables in the cointegration vector. This is done to make a preliminary decision on the direction of causality of the variables in the cointegration vector. Also, a test of zero restriction on the parameters of the cointegrating vector is conducted. A rejection of the null hypothesis signifies the importance of the variable in the vector. Each of the vectors is then normalised based on the theoretical postulates on the relationship between finance and growth.

\subsection{The Panel Unit Root}

The preliminary investigation commences with the confirmation of the degree of integration of each variable. The study conducts panel unit root tests. There are six popular panel unit root tests with varying assumptions about the autoregressive (AR) process, thus the study conducts four tests to confirm the reliability of the tests and then compare the results to check the robustness of the exercise. However these six tests can conveniently be classified into two main 
groups based on the assumption of the AR process in the series. The first group assumes that the series have a common root. This group includes Levin, Lin and Chu test (LLC, 1992), Breitung (2000), and Hadri (2000). The second group assumes that the series have individual root. This group includes Im, Pesaran and Shin (IPS, 1997), Fisher-ADF, and Fisher-PP tests. All the tests in the two groups with the exception of Hadri (2000) take non-stationarity (presence of unit root) as the null.

Furthermore, the series were estimated under three assumptions, (a) series were estimated with individual intercept so as to include the individual fixed effects, (b) series estimated with individual intercepts and individual trends, this is done to include both the fixed effects and trends, and (c) where none of the two options is included.

Table 1: Panel Unit Root Tests

\begin{tabular}{|c|c|c|c|c|c|c|c|c|c|c|}
\hline \multirow{5}{*}{ Variables } & \multirow{3}{*}{ Intercept } & \multirow{3}{*}{$\begin{array}{l}\text { Intercept } \\
\text { and Trend }\end{array}$} & \multicolumn{2}{|l|}{ LLC } & \multicolumn{2}{|c|}{ Breitung } & \multirow{3}{*}{$\begin{array}{l}\text { Intercept } \\
\text { and Trend }\end{array}$} & \multicolumn{3}{|c|}{ IPS } \\
\hline & & & Intercept & $\begin{array}{l}\text { Intercept } \\
\text { and Trend }\end{array}$ & $\begin{array}{c}\text { Intercept } \\
\text { and }\end{array}$ & Intercept & & Intercept & $\begin{array}{l}\text { Intercept } \\
\text { and Trend }\end{array}$ & $\begin{array}{c}\text { Order of } \\
\text { Integration }\end{array}$ \\
\hline & & & & & Trend & & & & & \\
\hline & At Level & At Level & In First & In First & At level & At Level & At Level & In First & In First & \\
\hline & & & Difference & Difference & & & & Difference & Difference & \\
\hline $\mathrm{LDC} / \mathrm{Y}$ & -0.71 & $-1.77 * *$ & $-8.93 * * *$ & $-8.83 * * *$ & 3.59 & -0.61 & 1.68 & $-11.17 * * *$ & $-10.51 * * *$ & $\mathrm{I}(1)$ \\
\hline $\mathrm{LDCp} / \mathrm{Y}$ & -0.46 & $2.69^{* *}$ & $-13.22 * * *$ & $-11.98 * * *$ & -0.26 & 0.18 & -0.58 & $-13.75^{* * *}$ & $-11.96^{* * *}$ & $\mathrm{I}(1)$ \\
\hline $\mathrm{LM} 3 / \mathrm{Y}$ & $-1.36^{*}$ & $-1.84 * *$ & $-12.52 * * *$ & $-10.85^{* *}$ & -1.12 & $-2.04 * *$ & -1.01 & $-15.93 * * *$ & $-14.39 * * *$ & $\mathrm{I}(1)$ \\
\hline $\mathrm{LM} 2 / \mathrm{Y}$ & -1.12 & $-2.08 * *$ & $13.30 * * *$ & $-12.45^{* * *}$ & 0.21 & -1.17 & -0.46 & $-14.16^{* * *}$ & $-12.53 * * *$ & $\mathrm{I}(1)$ \\
\hline LY & 1.35 & 6.25 & -1.25 & 1.52 & 1.09 & -0.58 & 1.63 & $-14.37 * * *$ & $-12.81 * * *$ & $\mathrm{I}(1)[1]$ \\
\hline LDCSA & 18.12 & 5.73 & $-12.49 * * *$ & $-18.71 * * *$ & 13.03 & 18.04 & 13.06 & $-10.66^{* * *}$ & $-18.16^{* * *}$ & $\mathrm{I}(1)$ \\
\hline LDCPSA & 6.42 & $-4.64 * * *$ & $-7.09 * * *$ & $-3.72 * * *$ & 1.29 & 10.69 & -1.04 & $-6.70 * * *$ & $-4.54 * * *$ & $\mathrm{I}(1)$ \\
\hline LM3SA & $-1.87^{* *}$ & 8.53 & $-11.88^{* * *}$ & $-12.26^{* * *}$ & 6.16 & 0.32 & 9.73 & $-12.52 * * *$ & $-13.39^{* * *}$ & $\mathrm{I}(1)$ \\
\hline LM2SA & 1.89 & 4.66 & $-16.96^{* * *}$ & $-19.04 * * *$ & 6.24 & -0.38 & 7.73 & $-12.30 * * *$ & $-13.45^{* * *}$ & $\mathrm{I}(1)$ \\
\hline
\end{tabular}

Table 2: Panel Unit Root at Level

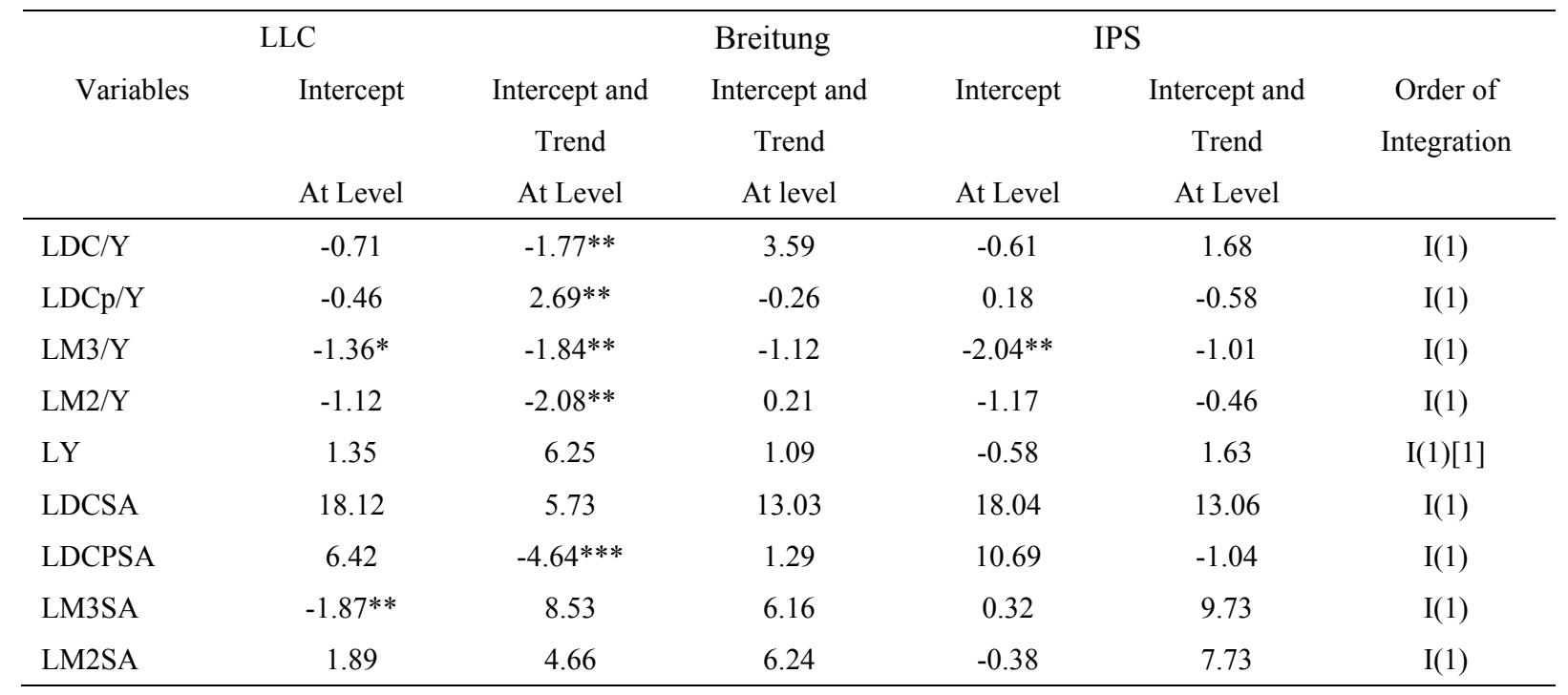


Table 3: Panel Unit Root at First Difference

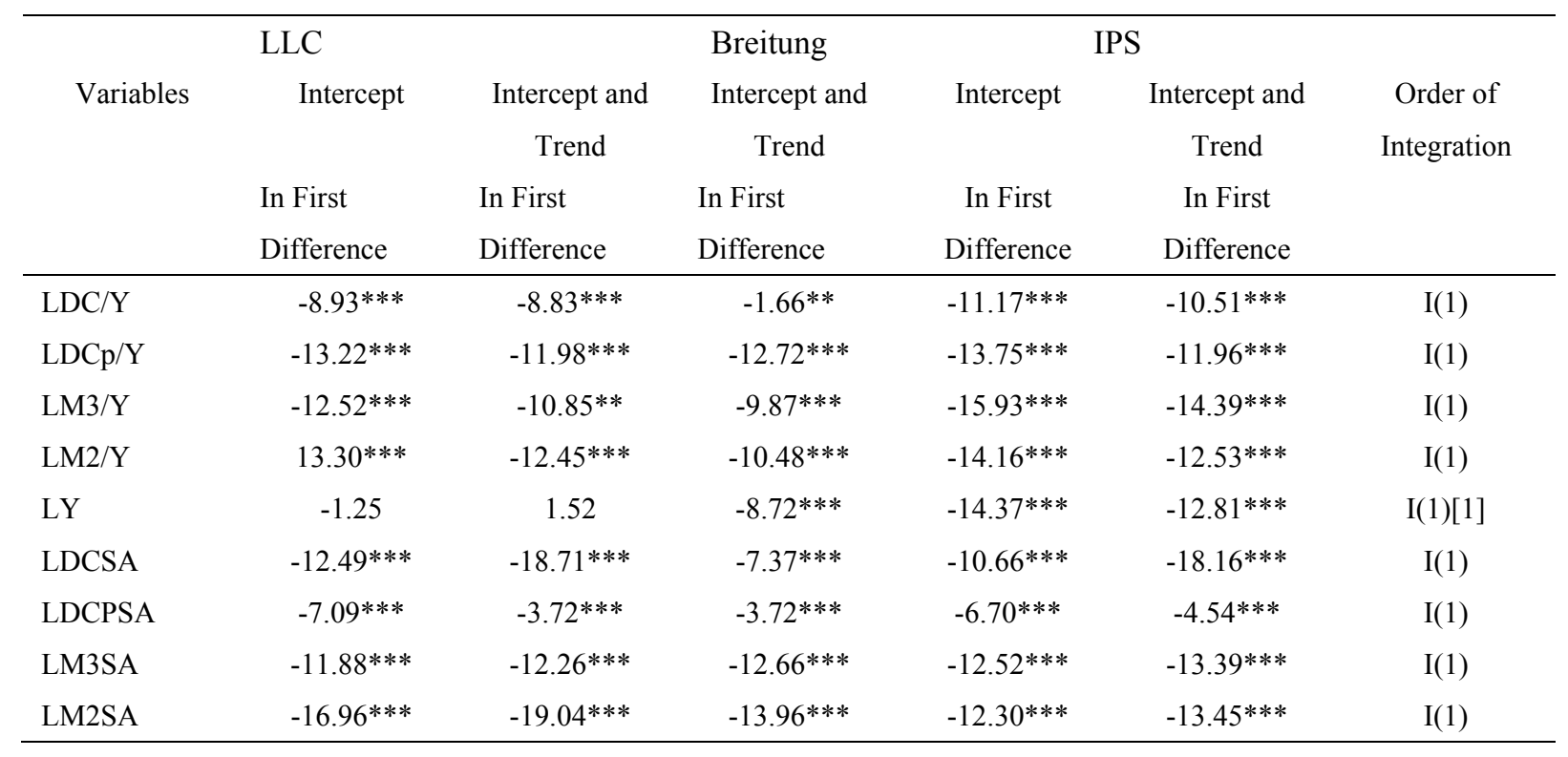

\subsection{Panel Cointegration}

This approach becomes much in use because of its inherent advantage of stronger power of the tests when pooling information across the i members of a panel.

Three panel cointegration tests were used in this study. These are the Pedroni (1999), Kao (1999) and Johansen tests. The Pedroni and Kao tests are residual-based cointegration tests based on the Engle-Granger (1987) two-step approach and single-equation framework, while the Johansen test is a multivariate test.

\subsubsection{Discussion on the Panel Cointegration Tests}

The availability of panel data has led to recent increase in empirical research on panel macroeconomic variables. The most popular panel cointegration tests include Pedroni(1999), 2004, Kao(1999), and a Fisher-type using an underlying Johansen methodology (Maddala and Wu 1999, Larsson et al 2001).

The critical value for the Pedroni tests is -1.64 (see Pedroni 1999 table 2), with the exception of the v-statistic that has a critical value of 1.64. Thus, any statistical value greater than -1.64 (in absolute term) implies the rejection of the null hypothesis of no cointegration (Asteriou and Hall, 2007, P376). Both Pedroni and Kao tests are all one-sided and with a critical value of 1.64 .

Sequel to the empirical finding that South Africa's financial development has exerted a significant impact on the financial development of neighbouring countries in SSA, we further explore whether this impact of spatial variable translates into any long run benefits to the financial sectors in particular and economic growth in general of these countries by conducting panel cointegration test for all the countries in the sample.

The panel unit root tests indicate that the variables are I(1) series, the result is shown in Tables 2 above. Thus the confirmation of the order of integration makes it econometrically reasonable 
to conduct the panel cointegration for all the countries as a group. The essence of this is to assess the long run impact of the spatial externality on the host financial development. If the variable is relevant, and has a long run impact on domestic financial development, then any omission of this variable in the formulation of financial development in the region may have serious consequence on the model specified. This could also enhance our understanding on the channels by which finance relates to economic growth.

The paper starts with a bivariate cointegration model, to establish the relationship between finance and growth as done by previous researchers, by testing the panel cointegration between the Real GDP and financial development indicators, then the study tests the weak exogeneity between the two variables to ascertain the direction of causality between the two.

From the bivariate model, the cointegration results suggest rejection of the null hypothesis of no cointegration between the variables. All the three tests suggest that there is cointegration. The sufficient condition to conclude existence of causality is for the alpha $(\alpha)$ coefficients in the VECM to be weakly exogenous. Hence, we conduct weak exogeneity test for each of the variables of interest. The null hypothesis is that the variable is weakly exogenous, and the alternative is that the variable is not. We do this by restricting the alpha coefficient of each variable of interest to zero, and check the LM and Chi square statistics.

The results (Tables 4 - 7) suggest that the model does not reject the null hypothesis of weak exogeneity, for the real GDP for all different indicators used. The $\alpha$ coefficients are statistically insignificant at the conventional $5 \%$ level. This lends empirical support to the view that the direction of causality is from real sector to financial development in the region. This indicates that the relationship between finance and growth follows demand following hypothesis (Patrick 1966) and exhibits reverse causality (Demetriades and Hussein 1996) in the region.

After this, the spatial variable was included in the cointegration vector. The relevance of this inclusion was tested to confirm its statistical importance in the cointegration vector. The study imposes a restriction on the coefficient of the $\beta$ and then conducts the likelihood ratio test on the coefficient of the new variable. The null hypothesis is that the variable is not important in the cointegration vector, thus a rejection of the null hypothesis signifies the importance of the variable in the vector. From Table 8, the results suggest that we do reject the null hypothesis, and conclude that the variable is important in the vector. We then further imposed restriction on the $\alpha$ to test the longrun impact and speed of adjustment to disequilibrium (the weak exogeneity restriction). The null hypothesis is that the variable is weakly exogenous, while the alternative hypothesis is that the variable is not weakly exogenous. In all, the study cannot reject the null hypothesis of the weak exogeneity of the spatial variable in 3 out of the four financial indicators; we do reject the null only when we use the domestic credit to the economy. However, the weak exogeneity tests for other variables are rejected, suggesting other variables are not weakly exogenous. The result is presented in table 8 below. Thus, we conclude that the spatial variable is an important determinant of financial development in the region. This further suggests that another possible transmission channel in the relationship between finance and 
growth in SSA, is the level of financial development in South Africa. The direction of causality is from financial development in South Africa to the financial sector in the other neighbouring countries. Some banks in South Africa have branches in 18 of the SSA countries in the sample, some big corporations in South Africa are equally the top largest companies in some Africa countries, for example, the MTN owned by SA is the largest Telecommunication firm in Nigeria, Stanbic (Standard-Charter Bank) is one of the biggest banks in Nigeria.

The result suggests that the spatial effect is significant in all cases, though it may crowd-out the domestic financial sector in the short-run, but it has a long run stable impact not only on the financial sector but also on the economy as a whole.

In summary, the results from the cointegration tests suggest that we reject the null hypothesis of no long-run stable relationship among the variables (using all the four indicators of financial development, since the hypothesis $H_{o}: \beta_{F d S A}=0$ is rejected in all the specifications. Similar trends hold for financial development and economic growth, the hypotheses $H_{o}: \beta_{f d}=0$. And $H_{o}: \beta_{y}=0$ are rejected mostly at conventional $5 \%$ statistical level.

However, another unique finding is that the null hypothesis of weak exogeneity cannot be rejected for the spatial variable. This suggests that there is a unidirectional causality (of the spatial variable) from South Africa financial development to the other countries and not the reverse. This is justified with the policy regime in South Africa that allows no exchange restrictions from South Africa to other countries but an enforcement of this exchange restriction from other countries to South Africa.

In all, the study finds statistical evidence that financial development exhibits spatial externality among these countries, and thus consideration of spatial variable may be an important determinant of financial development in these countries. Non recognition of this important variable may lead to omitted variable bias and its econometric implications.

The study then investigates further, by conducting the impulse response analysis on the variables, to assess how the financial sector in particular and the domestic economies in general respond to this exogenous spatial shock. 
Table 4: Panel Cointegration Test for Bivariate Models

\begin{tabular}{|c|c|c|c|c|c|}
\hline \multirow[b]{2}{*}{$\begin{array}{l}\text { Variables in Cointegration } \\
\text { Vector }\end{array}$} & \multirow[b]{2}{*}{ Test } & \multicolumn{2}{|c|}{ Pedroni } & & \multirow{2}{*}{$\begin{array}{l}\text { Kao } \\
\text { Test }\end{array}$} \\
\hline & & Intercept & $\begin{array}{l}\text { Intercept } \\
\text { and Trend }\end{array}$ & None & \\
\hline \multirow[t]{7}{*}{$\mathrm{Lm} 2, \quad \mathrm{LY}$} & panel -v & 1.48 & --1.59 & $3.28 * * *$ & $-2.84 * * *$ \\
\hline & panel - $\rho$ & -1.05 & 1.41 & $4.36 * * *$ & \\
\hline & panel - pp & $-2.12 * *$ & -0.22 & $4.76^{* * *}$ & \\
\hline & panel - Adf & $-1.86^{*}$ & -0.25 & $3.04 * * *$ & \\
\hline & Group - $\rho$ & 0.80 & $2.17 * *$ & -1.10 & \\
\hline & Group - pp & -0.94 & 0.18 & $3.69 * * *$ & \\
\hline & Group - Adf & -1.03 & -1.23 & $-2.77 * *$ & \\
\hline \multirow[t]{7}{*}{ Ldc, LY } & panel $-v$ & $4.81 * * *$ & 1.32 & $7.42 * * *$ & --0.85 \\
\hline & panel - $\rho$ & -0.39 & 0.92 & $-2.26^{* *}$ & \\
\hline & panel - pp & -0.62 & -0.53 & $-2.23 * *$ & \\
\hline & panel - Adf & 0.22 & 0.72 & $-2.23 * *$ & \\
\hline & Group - $\rho$ & $1.92 *$ & $3.15 * * *$ & $1.77 *$ & \\
\hline & Group - pp & 0.23 & 0.37 & $-2.69 * *$ & \\
\hline & Group - Adf & 0.46 & 1.15 & $-2.22 * *$ & \\
\hline
\end{tabular}


Table 4: Contd: Panel Cointegration Test for Bivariate Models

\begin{tabular}{|c|c|c|c|c|c|}
\hline $\begin{array}{l}\text { Variables in } \\
\text { Cointegration Vector }\end{array}$ & Test & Intercept & $\begin{array}{l}\text { Pedroni } \\
\text { Intercept } \\
\text { and Trend }\end{array}$ & None & $\begin{array}{l}\text { Kao } \\
\text { Test }\end{array}$ \\
\hline \multirow[t]{7}{*}{$\mathrm{Lm} 3, \mathrm{LY}$} & panel -v & 1.62 & --1.65 & $3.52 * * *$ & $--2.55 * * *$ \\
\hline & panel - $\rho$ & $-2.28 * *$ & 0.09 & $-5.92 * * *$ & \\
\hline & panel - pp & $-3.26 * * *$ & $-1.86^{*}$ & $-5.97 * * *$ & \\
\hline & panel - Adf & $-2.27 * *$ & -0.45 & $-3.42 * * *$ & \\
\hline & Group - $\rho$ & -1.27 & 0.31 & $-2.69 * *$ & \\
\hline & Group - pp & $-3.46^{* * *}$ & $-2.53 * *$ & $5.30 * * *$ & \\
\hline & Group - Adf & $-2.48 * *$ & -1.48 & $-3.79 * * *$ & \\
\hline \multirow[t]{7}{*}{ LDCp, LY } & panel -v & $8.19 * * *$ & $8.11 * * *$ & $-3.59 * *$ & $-2.84 * * *$ \\
\hline & panel - $\rho$ & $-15.6 * * *$ & $-18.5 * * *$ & -1.07 & \\
\hline & panel - pp & $-27.5 * * *$ & $-30.3 * * *$ & $-1.69 * *$ & \\
\hline & panel - Adf & -1.52 & $-3.12 * * *$ & -1.59 & \\
\hline & Group - $\rho$ & -0.29 & 0.13 & 2.01 & \\
\hline & Group - pp & $-2.81 * * *$ & $-1.94 * *$ & -1.13 & \\
\hline & Group - Adf & -0.25 & -0.14 & -1.12 & \\
\hline
\end{tabular}


Table 5: Panel Cointegration Test for Trivariate Models

\begin{tabular}{|c|c|c|c|c|c|}
\hline $\begin{array}{l}\text { Variables in } \\
\text { Cointegration Vector }\end{array}$ & Test & Intercept & $\begin{array}{l}\text { Pedroni } \\
\text { Intercept } \\
\text { and Trend }\end{array}$ & None & $\begin{array}{l}\text { Kao } \\
\text { Test }\end{array}$ \\
\hline \multirow[t]{7}{*}{ Lm2, LM2SA, LY } & panel -v & 0.27 & $-2.08 * *$ & 0.88 & $-2.83 * * *$ \\
\hline & panel - $\rho$ & 0.33 & $2.46^{* *}$ & 0.06 & \\
\hline & panel - pp & -0.67 & 0.99 & -0.77 & \\
\hline & panel - Adf & $-1.72 *$ & -0.33 & -0.91 & \\
\hline & Group - $\rho$ & $1.90 *$ & $3.17 * * *$ & 1.29 & \\
\hline & Group - pp & 0.39 & 0.79 & -0.03 & \\
\hline & Group - Adf & -0.76 & $-1.97 *$ & -0.51 & \\
\hline \multirow[t]{7}{*}{ Ldc, LDCSA, LY } & panel - v & $2.16^{* *}$ & 0.32 & $2.48 * *$ & $--2.91 * * *$ \\
\hline & panel - $\rho$ & -0.38 & 0.15 & -1.10 & \\
\hline & panel - pp & $-1.88 * * *$ & $-2.08 * *$ & $-2.65^{* *}$ & \\
\hline & panel - Adf & -1.51 & -1.17 & $-2.17 * *$ & \\
\hline & Group - $\rho$ & -0.20 & 0.76 & -0.33 & \\
\hline & Group - pp & $-4.05^{*}$ & $-3.57^{*}$ & $-4.77^{*}$ & \\
\hline & Group - Adf & $-2.75^{*}$ & -1.50 & $-3.73 *$ & \\
\hline
\end{tabular}




\begin{tabular}{|c|c|c|c|c|c|}
\hline $\begin{array}{l}\text { Variables in } \\
\text { Cointegration Vector }\end{array}$ & Test & Intercept & $\begin{array}{l}\text { Pedroni } \\
\text { Intercept } \\
\text { and Trend }\end{array}$ & None & $\begin{array}{l}\text { Kao } \\
\text { Test }\end{array}$ \\
\hline \multirow[t]{7}{*}{ Lm3, LM3SA, LY } & panel -v & 0.73 & $-1.83 *$ & $1.75^{*}$ & \multirow[t]{7}{*}{$--2.89 * * *$} \\
\hline & panel - $\rho$ & -0.77 & 1.35 & -0.63 & \\
\hline & panel - pp & $-2.26 * *$ & -1.38 & -1.44 & \\
\hline & panel - Adf & $-1.73 *$ & -0.73 & -0.88 & \\
\hline & Group - $\rho$ & -0.33 & 1.05 & -0.39 & \\
\hline & Group - pp & $-3.06 * * *$ & $-3.68 * * *$ & $-2.13 * *$ & \\
\hline & Group - Adf & $-2.49 * *$ & $-2.81 * * *$ & -1.47 & \\
\hline \multirow[t]{7}{*}{ LDCp, LDCpSA, LY } & panel -v & $2.48 * *$ & 0.23 & $2.64 * *$ & \multirow[t]{7}{*}{$-1.64 * *$} \\
\hline & panel - $\rho$ & $-2.06 * *$ & -0.03 & $-1.88^{*}$ & \\
\hline & panel - pp & $-3.42 * * *$ & $-2.22 * *$ & $-3.37 * * *$ & \\
\hline & panel - Adf & $-4.28 * * *$ & $-2.99 * *$ & $-3.92 * * *$ & \\
\hline & Group - $\rho$ & -1.23 & 0.56 & -0.84 & \\
\hline & Group - pp & $-4.32 * * *$ & $-3.78 * * *$ & $-4.25 * * *$ & \\
\hline & Group - Adf & $-4.33 * * *$ & $-3.06^{* * *}$ & $-4.75 * * *$ & \\
\hline
\end{tabular}


Table 6: Johansen Panel Cointegration (Bivariate)Tests

\begin{tabular}{|c|c|c|c|c|}
\hline \multirow{2}{*}{$\begin{array}{l}\text { Variables in } \\
\text { cointegration } \\
\text { vector }\end{array}$} & \multicolumn{2}{|c|}{$\begin{array}{l}\text { Trace Statistic } \\
\text { (Fisher stat) }\end{array}$} & \multicolumn{2}{|c|}{$\begin{array}{c}\text { Maximal Eigenvalue } \\
\text { (Fisher Stat) }\end{array}$} \\
\hline & $\mathrm{r}=0$ & $\mathrm{r}=1$ & $\mathrm{r}=0$ & $\mathrm{r}=1$ \\
\hline LDC, LY & $106.7^{* * *}$ & $109.2 * * *$ & $80.94 * * *$ & $109.2 * * *$ \\
\hline LDCp, , LY & $96.72 * * *$ & $87.11 * * *$ & $81.70 * * *$ & $87.11 * * *$ \\
\hline LM2, LY & $88.6 * * *$ & $102.3 * * *$ & $68.2 * *$ & $102.3 * * *$ \\
\hline LM3, LY & $100.3^{* * *}$ & $104.2 * * *$ & $76.3 * *$ & $104.2 * * *$ \\
\hline
\end{tabular}

Table 7: Johansen Panel Cointegration (Trivariate) Tests

\begin{tabular}{lcccccc}
\hline Variables in & \multicolumn{3}{c}{ Trace Statistic } & \multicolumn{3}{c}{ Maximal Eigenvalue } \\
cointegration & \multicolumn{3}{c}{ (Fisher stat) } \\
\multicolumn{1}{c}{ vector } & $\mathrm{r}=0$ & $\mathrm{r}=1$ & $\mathrm{r}=2$ & $\mathrm{r}=0$ & $\mathrm{r}=1$ & $\mathrm{r}=2$ \\
\hline LDC, LY, & $141.2^{* * *}$ & $77.52^{* * *}$ & $66.60^{* *}$ & $102.8^{* * *}$ & $68.83^{* *}$ & $66.50^{* *}$ \\
LDSADC & $(0.000)$ & $(0.002)$ & $(0.03)$ & $(0.000)$ & $(0.02)$ & $(0.03)$ \\
LDC, LY, & $141.2 * * *$ & $77.52^{* * *}$ & $66.60^{* *}$ & $102.8^{* * *}$ & $68.83 * *$ & $66.50^{* *}$ \\
LDSADC & $(0.000)$ & $(0.002)$ & $(0.03)$ & $(0.000)$ & $(0.02)$ & $(0.03)$ \\
LDCp, LY, & $139.2 * * *$ & $60.19^{*}$ & 41.88 & $121.1 * * *$ & 58.31 & 41.88 \\
LDSADCp & $(0.000)$ & $(0.07)$ & $(0.64)$ & $(0.000)$ & $(0.11)$ & $(0.64)$ \\
LM2, & $89.57 * * *$ & $62.28^{*}$ & $85.73 * * *$ & $59.80^{*}$ & 44.94 & $85.73 * * *$ \\
LY,LDSAM2 & $(0.00)$ & $(0.06)$ & $(0.00)$ & $(0.08)$ & $(0.52)$ & $(0.00)$ \\
LM3, & $102.6^{* * *}$ & $62.14^{*}$ & 107.4 & $75.43^{* * *}$ & 36.20 & 107.4 \\
LY,LDSAM3 & $(0.00)$ & $(0.06)$ & $(0.00)$ & $(0.00)$ & $(0.85)$ & $(0.00)$ \\
\hline
\end{tabular}

Table 8: Test of Significance of the Variables in the Panel Cointegration of the Bivariate Models

\begin{tabular}{|c|c|c|c|c|}
\hline \multicolumn{3}{|c|}{ Null Hypothesis: $\beta_{i}=0$} & \multicolumn{2}{|c|}{ Null Hypothesis: $\alpha_{i}=0$} \\
\hline Variables & $H_{o}: \beta_{f d}=0$ & $H_{o}: \beta_{y}=0$ & $H_{o}: \alpha_{f d}=0$ & $H_{o}: \alpha_{y}=0$ \\
\hline LDC, LY & $17.89 * * *$ & 1.01 & $13.06 * * *$ & 2.45 \\
\hline LDCp, LY & $8.34 * * *$ & 0.44 & $8.67 * * *$ & 0.37 \\
\hline Lm2, ,LY & $12.66^{* * *}$ & 0.96 & $11.97 * * *$ & 0.01 \\
\hline $\mathrm{Lm} 3$, ,LY & $17.69 * * *$ & 1.69 & $17.74 * * *$ & 0.02 \\
\hline
\end{tabular}




\section{1) Macrothink}

Table 9: Test of Significance of the Variables in the Panel Cointegration of the Trivariate Models

Null Hypothesis: $\beta_{i}=0$

\begin{tabular}{lllllll}
\hline Variables & $H_{o}: \beta_{f d}=0$ & $H_{o}: \beta_{F d S A}=0$ & $H_{o}: \beta_{y}=0$ & $H_{o}: \alpha_{f d}=0$ & $H_{o}: \alpha_{F D S A}=0$ & $H_{o}: \alpha_{y}=0$ \\
LDC, LY, & $29.02^{* * *}$ & $26.23^{* * *}$ & $16.72^{* * *}$ & $19.80^{* * *}$ & 0.40 & $5.08^{* *}$ \\
LDCSA & & & & & & \\
LDcp, & $9.03^{* * *}$ & $5.04^{*}$ & $8.11^{* *}$ & $8.52^{* * *}$ & 0.01 & 1.14 \\
LdcpSa,LY & & & & & & \\
Lm2,Lm2SA,LY & $16.24 * * *$ & $17.42^{* * *}$ & $8.05^{* *}$ & $12.12^{* * *}$ & 0.36 & 0.99 \\
Lm3,Im3SA,LY & $17.82^{* * *}$ & $18.46^{* * *}$ & $10.35^{* *}$ & $16.88^{* * *}$ & 0.09 & 0.72 \\
\hline
\end{tabular}

\section{The Impulse Response}

This further leads to an inquiry into how the financial development in these countries in particular as well as the overall economy responds to this exogenous shock, (spatial externality). Thus we conduct the impulse response test analysis. This was done by using the recursive model of the Choleski decomposition method. This method assumes that each variable does not have a contemporaneous effect. However this approach has been criticised, for being mechanical without any economic basis.

Enders (2004) observes that the innovations in Choleski decomposition do not have a direct economic interpretation. He suggests that although this may not pose many problems in case of forecasting, but if one is interested in impulse response function or variance decomposition for economic analysis, then the structural VAR model is better. Thus, this thesis conducts both structural VAR decomposition method and the Choleski method. Since the aim of the structural VAR is to use economic theory (rather than the Choleski decomposition) See also Sims (1986) and Bernanke (1986) Blanchard and Quah 1989).

(Blanchard and Quah.1989) provide an alternative way to obtain a structural VAR, by reconsidering the Beveridge and Nelson 1981 decomposition. They decompose pure shock into temporary (short run) and permanent (long run) component.

The results are presented in both pictorial and tabulated forms (see figures 1-4, and Table 10) using the graphical method and table for these

Table 10: Impulse response from Weakly Exogenous Spatial Variable

\begin{tabular}{llll}
\hline FD Proxy & Period & FD & LY \\
\hline LDSADC & 1 & -0.00 & 0.00 \\
& 5 & -0.01 & 0.04 \\
& 10 & -0.01 & 0.04 \\
LDSADCp & 1 & -0.01 & 0.00 \\
& 5 & -0.01 & -0.01 \\
& 10 & -0.01 & -0.01 \\
\hline
\end{tabular}




\begin{tabular}{llll}
\hline LDSAM2 & 1 & 0.00 & 0.00 \\
& 5 & 0.00 & 0.00 \\
LDSAM3 & 10 & 0.00 & 0.00 \\
& 1 & 0.003 & 0.01 \\
& 5 & 0.004 & 0.01 \\
& 10 & 0.004 & 0.01 \\
\hline
\end{tabular}

It is striking to observe that the impulse response of spatial variable to FD and LY are different (though quite small) depending on the financial development indicator used. While for LDC and LDCp the signs are negative, but for LM2 and LM3 the signs are positive, this collaborates the earlier findings from the GMM estimations. The results suggest that the spatial variable has a substitution and crowding-out effect on the domestic credit market but a complementary effect on the money market in the region. However, it has overall positive growth effect on the economies (see Figures 1- 4 for the impulse response graphs)

The finding further suggests that this spatial externality may lead to an improvement in the economic growth. The response of the real GDP (LY) has been positive for most periods even though its impact is very small in these economies.

The impulse response of the spatial variable on itself suggests how South Africa economy responds to shock in the financial sector of South Africa. The result indicates low persistence rate and high adjustment rate using all the financial indicators. This suggests that the exogenous shock in the financial sector dies off quickly. This is a reflection of how financially developed the country is, or perhaps an indication of potency of monetary and stabilisation policy in the country. 
Response to Structural One S.D. Innovations \pm 2 S.E.
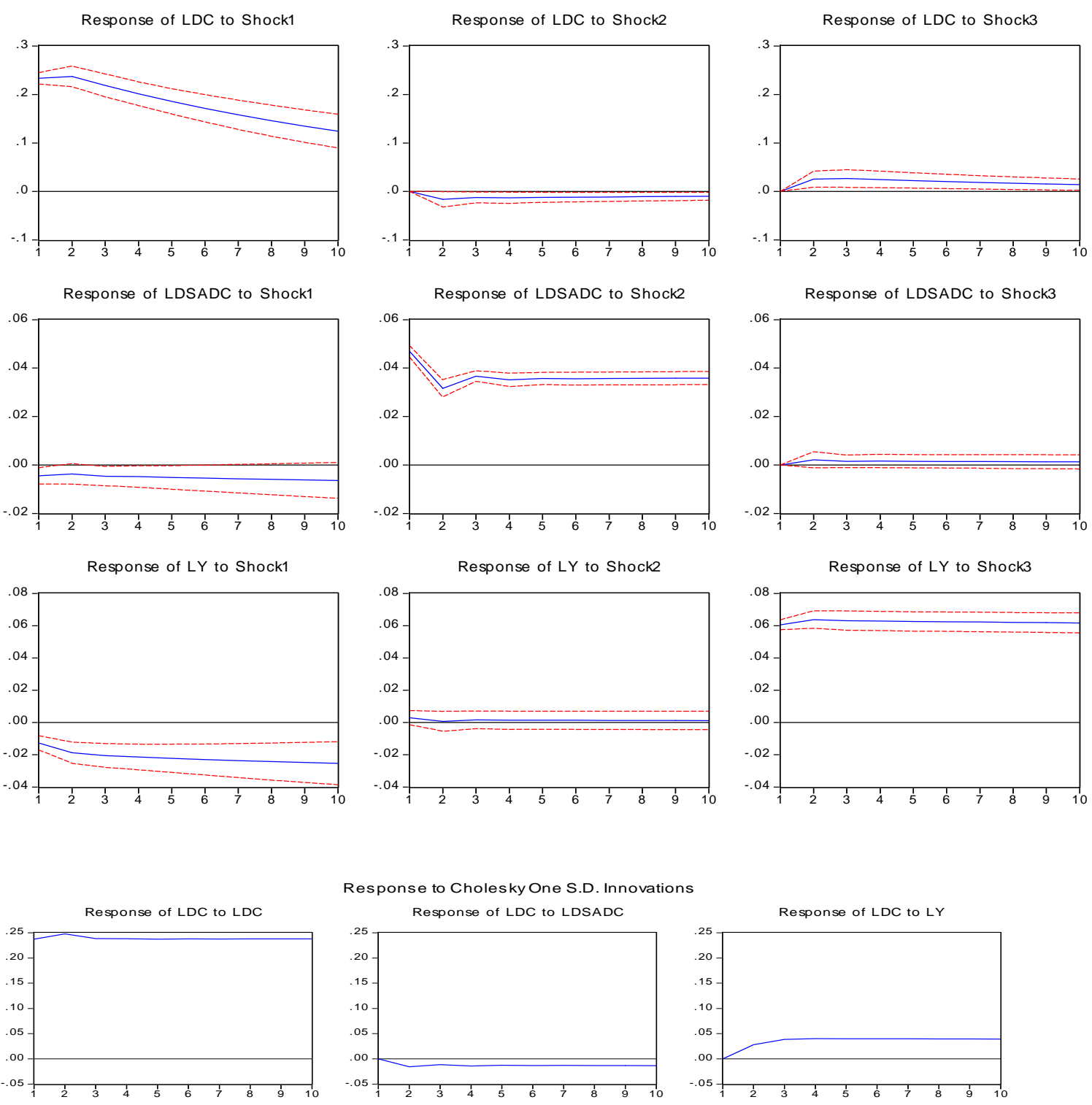

Response to Cholesky One S.D. Innovations
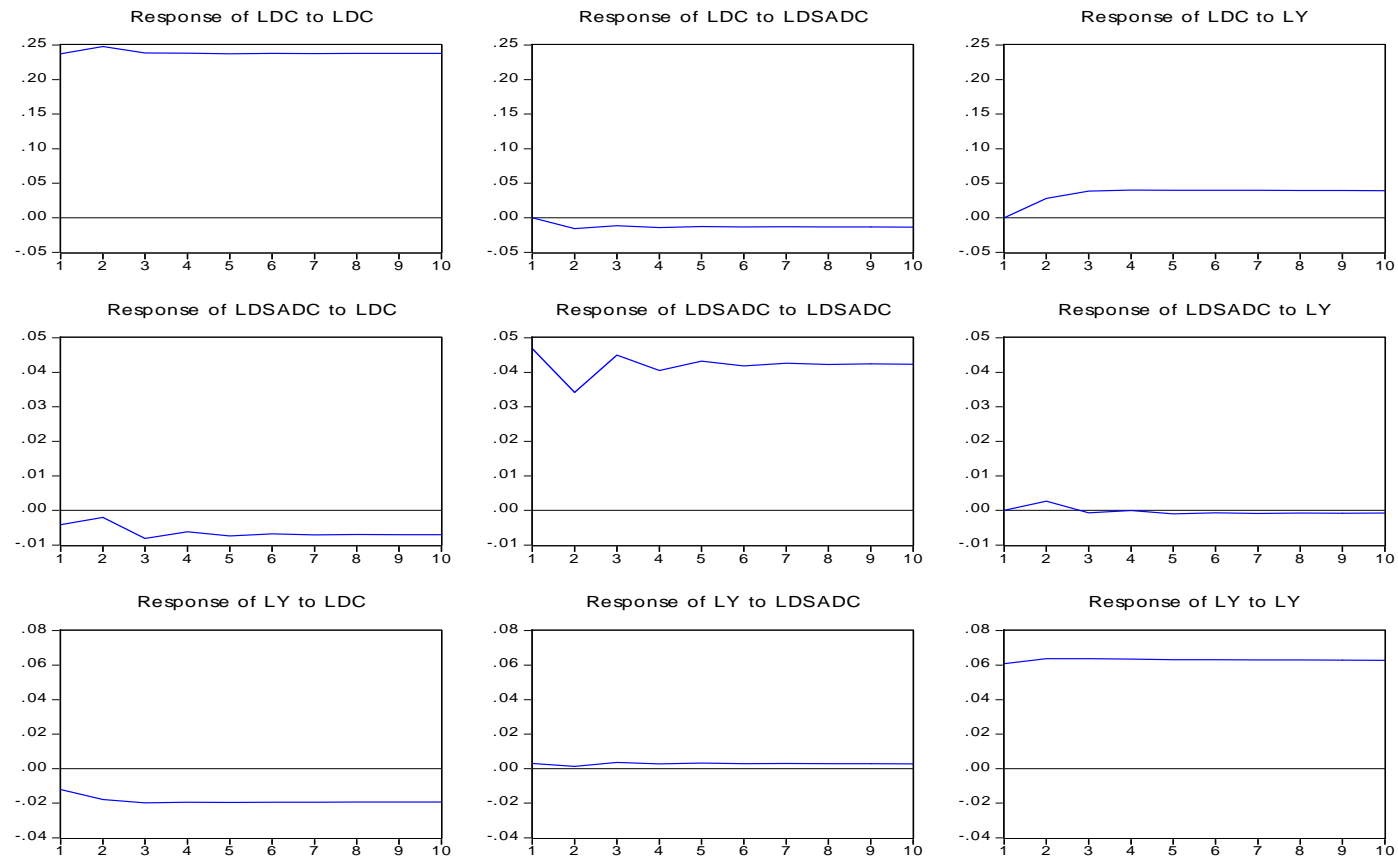

Figure 1: Impulse Response of the Domestic Credit to Spatial Externality 
Response to Structural One S.D. Innovations \pm 2 S.E.

Response of LDCP to Shock1

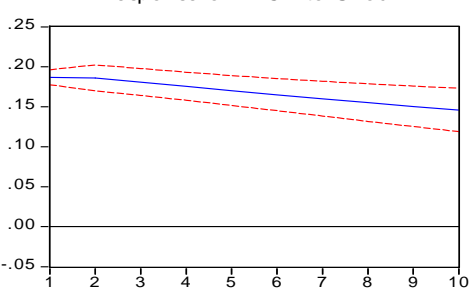

Response of LDSADCP to Shock1

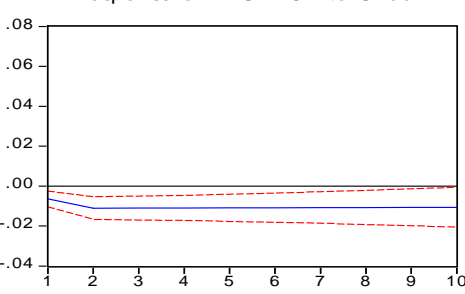

Response of LY to Shock1

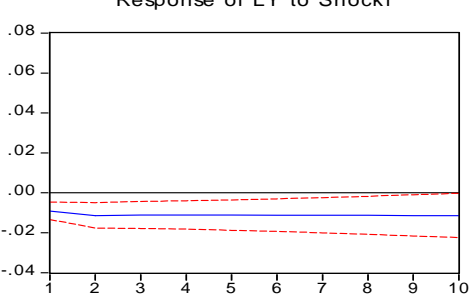

Response of LDCP to LDCP

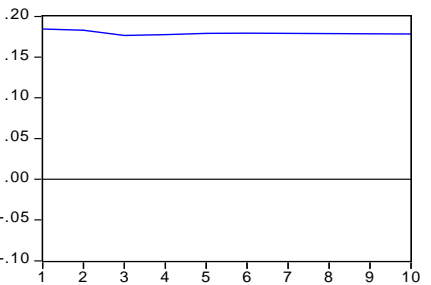

Response of LDSADCP to LDCP

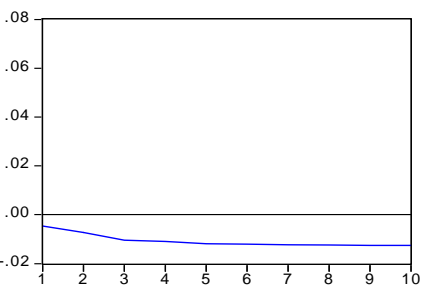

Response of LY to LDCP

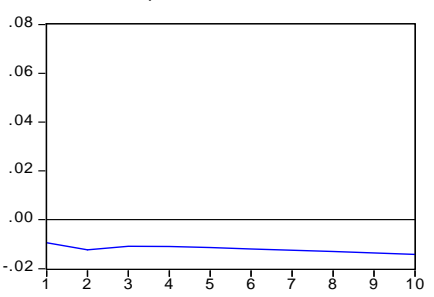

Response of LDCP to Shock2

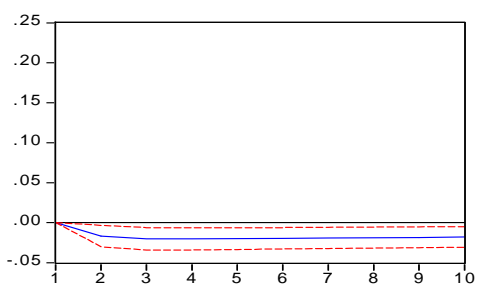

Response of LDSADCP to Shock

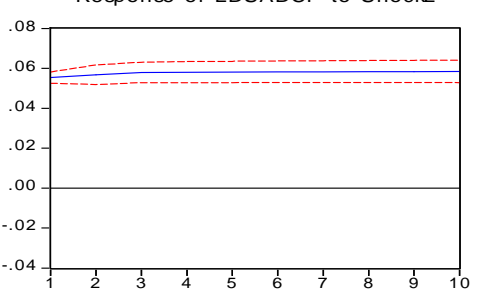

Response of LY to Shock2

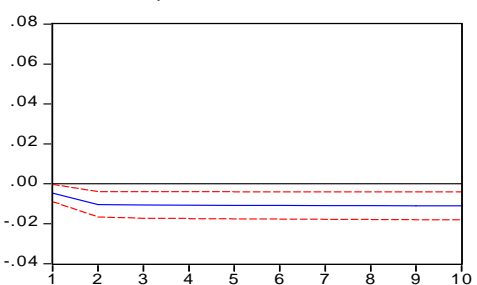

Response to Cholesky One S.D. Innovations

Response of LDCP to LDSADCP

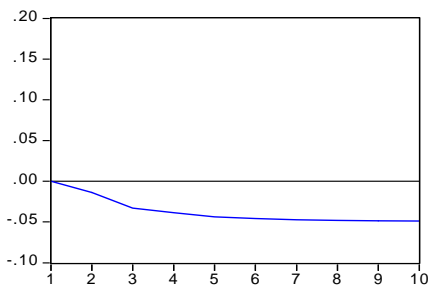

Response of LDSADCP to LDSADCP

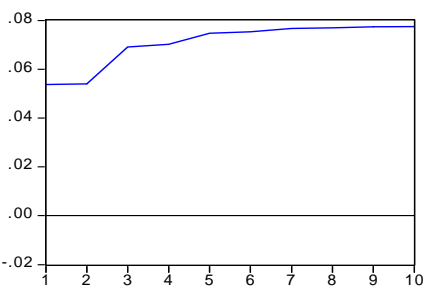

Response of LY to LDSADCP

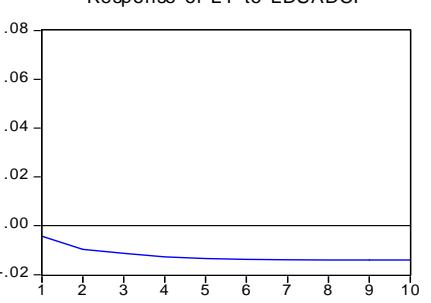

Response of LDCP to Shock3

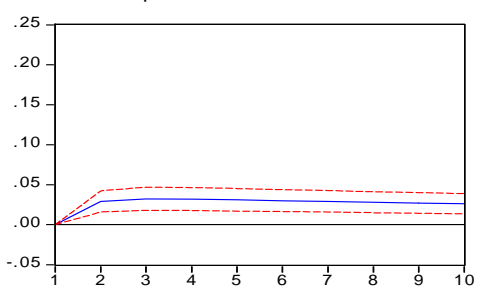

Response of LDSADCP to Shock3

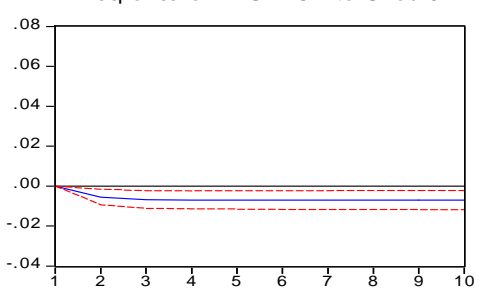

Response of LY to Shock3

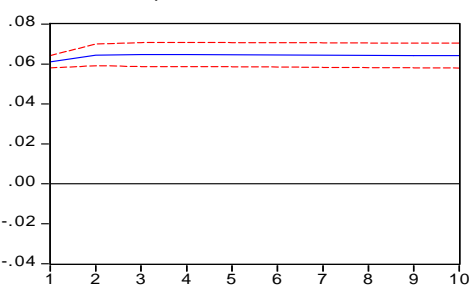

Figure 2: Impulse Response of the Private Credit to Spatial Externality 


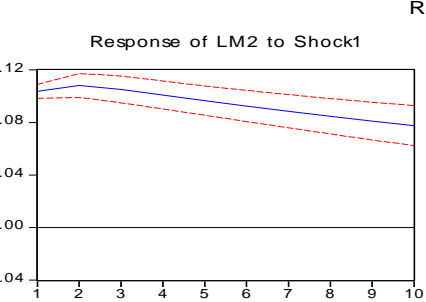

Response to Structural One S.D. Innovations \pm 2 S.E.
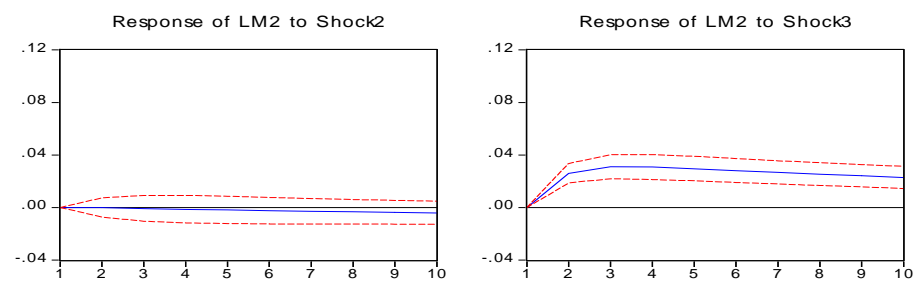

Response of LDSAM2 to Shock1
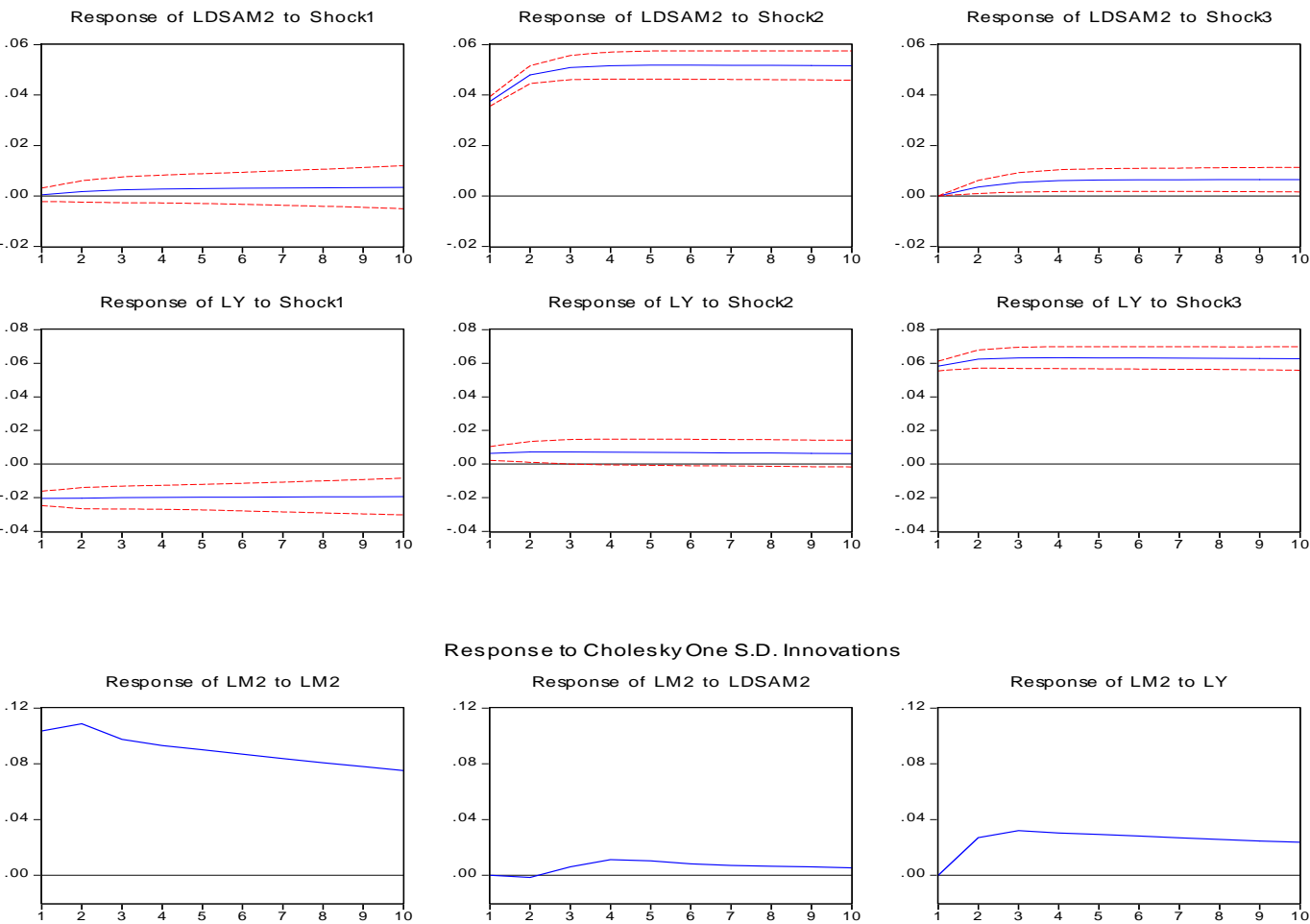

Response to Cholesky One S.D. Innovations
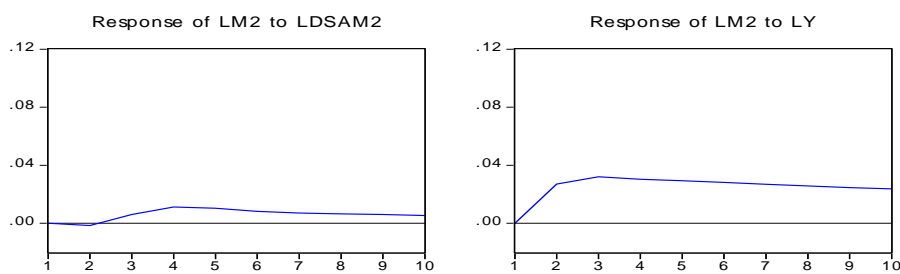

Response of LDSAM2 to LM2

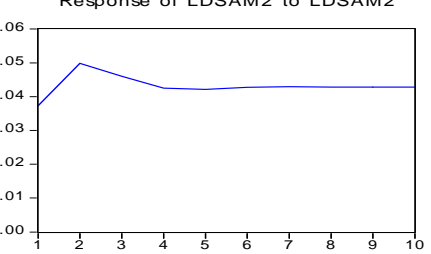

Response of LDSAM2 to LY

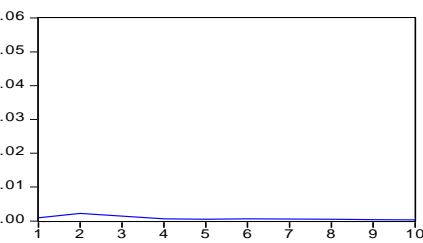

Response of $L Y$ to $L M 2$
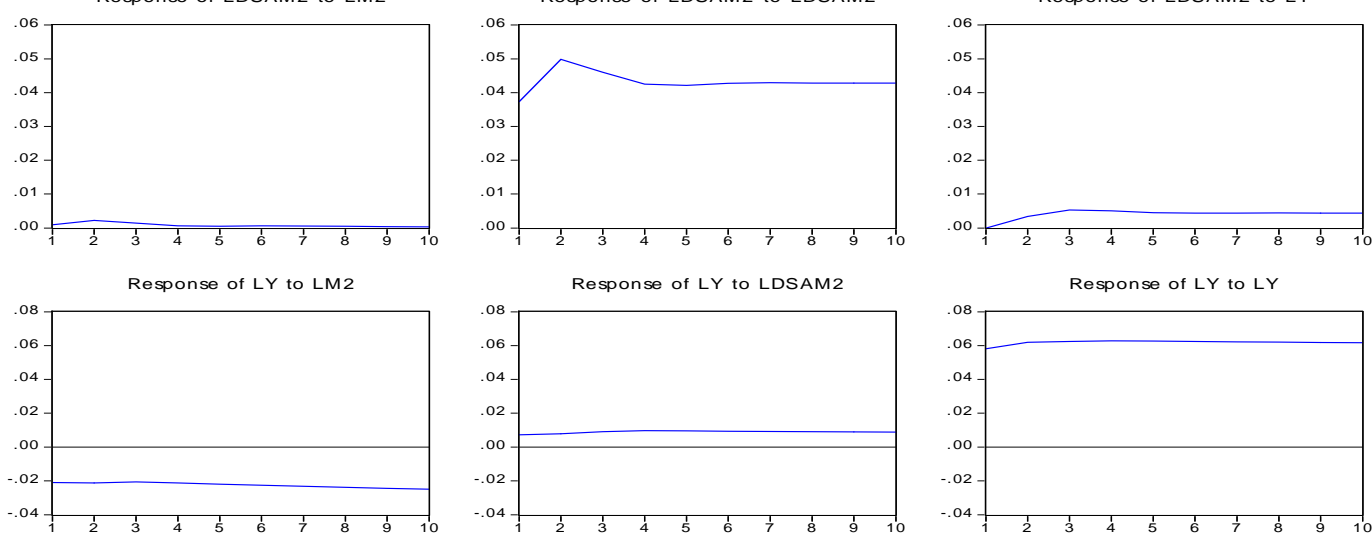

Figure 3: Impulse Response of the Broad Money to Spatial Externality 


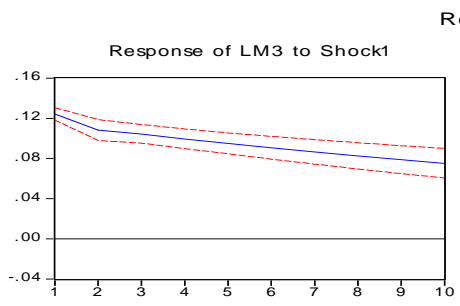

Response to Structural One S.D. Innovations \pm 2 S.E.
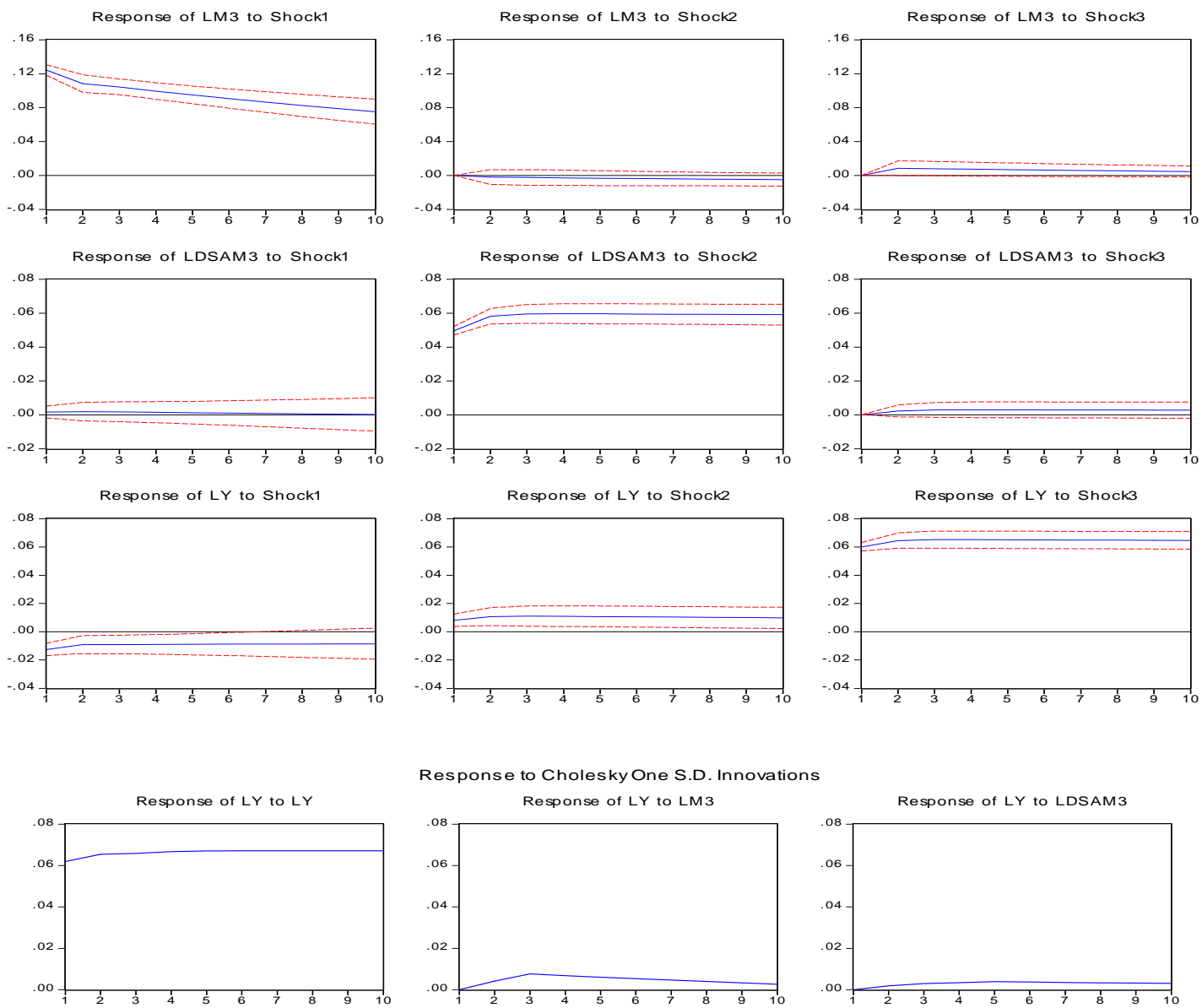

Response to Cholesky One S.D. Innovations
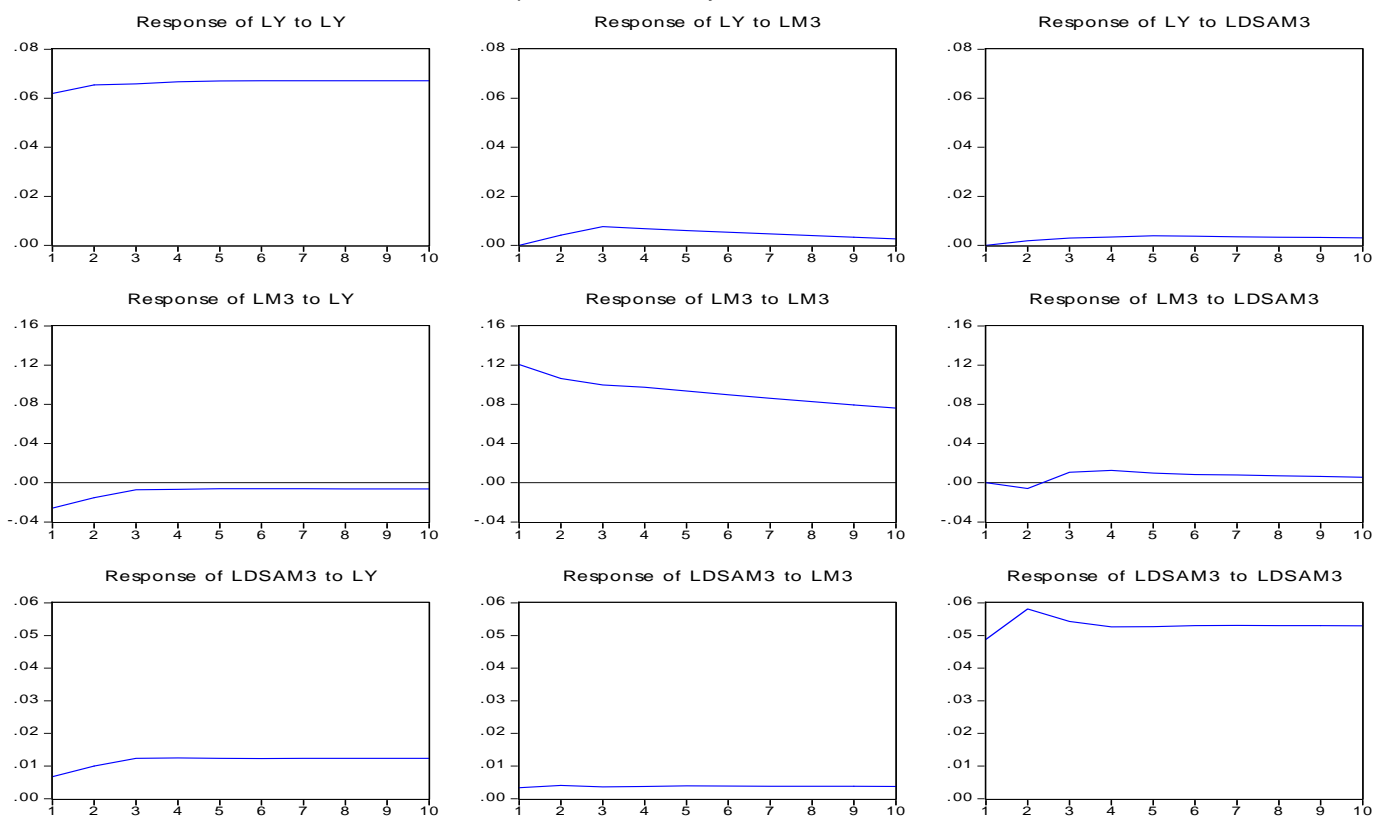

Figure 4: Impulse Response of the Liquid Liabilities to Spatial Externality

\section{Sensitivity Analysis}

We equally assess the long run impact of spatial variable on financial development and economic growth in 22 of the 24 countries in the panel, excluding both South Africa and Mauritania because of the extreme spatial weight. The results suggest that the spatial variable is significant in 19 countries, and it is weakly exogenous in 12 countries suggesting the variable is important in the region's financial development. 


\section{Conclusion}

The study uses the newly developed panel cointegration analysis to determine the long run stable relationship between the spatial variable, financial development and economic growth in SSA. The null hypothesis of no cointegration relationship among the variables is rejected for all the different financial development indicators used.

The study finds that real GDP causes economic growth in the region, and thus concludes that the relationship between finance and growth follows demand follow hypothesis. The study finds statistical evidence for the relevance of the spatial variable. It also finds that spatial variable has a long run impact on both financial development and economic growth in the sample countries. The speed of adjustment to long-run changes in the spatial variables is slow, suggesting considerable persistence of spatial exogenous shock. Positive shock is observed with the monetary indicators suggesting a complementary effect on the domestic money market, while a negative shock is observed in terms of credit indicators, this may suggest substitution and crowding -out effect on the domestic credit market.

In the finance literature, most empirical works on SSA document a reverse causality, from economic growth to finance, supporting the demand-following hypothesis, this has largely been attributed to the level of financial underdevelopment, and the policy prescription has been improvement in factors inhibiting financial development, this study however suggests another possible channel for financial development in the region. It suggests that spatial consideration of financial development might be another channel, as can be seen from the study that the financial development in South Africa does have impact not only on financial development in the neighbouring countries but also their economies.

Hence, the closer a country is to a more financially developed economy that generates spill over, the better the relationship between finance and growth.

Thus, recognising the financial development of a dominant neighbouring country may help us understand the relationship between finance and growth in each domestic country. The financial crisis in the mortgage-finance industry in US and its attendant spill over effects on other neighbouring countries provides a fresh memory of the importance of spatial externality in the financial sector. Thus, this study suggests careful consideration of spatial impact in our understanding of the finance-growth nexus.

The second implication is that spatial externality in the financial sector can positively enhance growth in these economies. Thus, this gives a theoretical basis for better regional cooperation, especially as Africa moves towards evolving policies that would help it reduce economic marginalisation of the region.

According to Honohan (2008), one of the major obstacles to financial development is high cost of credit and low access to credit in the region. He observes that only one out of every five adults in SSA has access to credit. The implication of this study therefore is that allowing spatial externality in the financial sector would increase access to credit while reducing the cost of credit in the region. Thus, it would enhance the quality and quantity of investment and overall economic growth in the region. The second implication is that the real economy 
positively responds to the spatial externality, suggesting a positive feedback mechanism on the economy.

Honohan 2008 also identifies the potential source of financial development in SSA, through regional financial cooperation, suggesting that this would enhance skill development, banking supervision and regulations, sharing financial credit history and best banking practices. Thus, this study, suggests that consideration of spatial financial effect could be a potential channel for actualising this regional financial cooperation and development.

Finally, the spatial externality model has two major transmission mechanisms on domestic financial sectors in particular and the economy, the first is through increasing access to credit and reduction of cost of credit, and the second is through enhancing regional cooperation through sharing financial records, best banking practises and lower supervision costs.

\section{References}

Ajayi, S.I (2003). Globalization and Africa. Journal of African Economies, 12(1), 120-150. http://dx.doi.org/10.1093/jae/12.suppl_1.120

Akinlo, A. E., \& Egbetunde, T. (2010). Financial Development and Economic Growth: The Experience of 10 Sub-Saharan African Countries Revisited. The Review of Finance and Marketing, 2(1).

Ang, J.B (2008). What are the Mechanisms linking Financial Development and Economic Growth in Malaysia. Economic Modelling, 25, 38-53. http://dx.doi.org/10.1016/j.econmod.2007.04.006

Arestis, P., \& P. Demetriades (1997). Financial Development and Economic Growth: Assessing the Evidence. Economic Journal, 107, 783-799. http://dx.doi.org/10.1111/j.1468-0297.1997.tb00043.x

Bagehot, W. (1873). Lombard Street. Homewood, IL: Richard D. Irwin, (1962 Edition).

Baltagi, B. (2005). Econometric Analysis of Panel Data. Chichester, UK: John Wiley.

Baltagi, B. (2008). Econometric Analysis of Panel Data(Fourth edition). Chichester, UK: John Wiley.

Bencivenga, V R., \& Smith, B D (1991). Financial Intermediation and Endogenous Growth. Review of Economic Studies, 58, 195-209. http://dx.doi.org/10.2307/2297964

Bernanke, B (1986). Alternative Explanations of Money-Income Correlation. Carnegie-Rochester Conference Series on Public Policy, 25, 49-100. http://dx.doi.org/10.1016/0167-2231(86)90037-0

Beveridge, S., \& Nelson, C (1981). A New Approach to Decomposition of Economic Time Series into Permanent and Transitory components with Particular Attention to measurement of the Business cycle. Journal of Monetary Economics, 7, 151-74. 
http://dx.doi.org/10.1016/0304-3932(81)90040-4

Blanchard, O., \& Quah, D (1989). The Dynamic Effects of Aggregate Demand and Supply Disturbances. American Economic Review, 79, 655-673.

Breitung, J (2000). "The Local Power of some Unit Root Tests for Panel Data” in Baltagi, (ed), Nonstationary Panels, Panel Cointegration and Dynamic Panels, Advances in Econometrics, 15, 161-78.

Calderon, C., \& Liu, L. (2003). The Direction of Causality between Financial Development and Economic Growth. Journal of Development Economics, 72(1), 321-334. http://dx.doi.org/10.1016/S0304-3878(03)00079-8

Dabos, M. T., \& Gantman, E. R. (2010). The Fading Link? A New Analysis of the Relationship Between Financial Development and Economic Growth. MFI Working Paper Series No. 2010-013

Deaton, A. (1995). "Data and Econometric tools for Development Analysis", Chapter 33 in J.Behrman and T.Srinivasan, eds, Handbook of Development Economics, Elsevier science, Amsterdam.

De Gregorio, J., \& Guidotti, P (1995). Financial Development and Economic Growth. World Development, 23, 433-448. http://dx.doi.org/10.1016/0305-750X(94)00132-I

Demetriades, P., \& Andrianova, S. (2004). Finance and Growth: What We Know and We Need to Know" in C. Goodhart, (ed.), Financial Development and Economic Growth: Explaining the Links, 38-65. Palgrave Macmillan, Basingstoke.

Demetriades, P.O., \& Hussein, K. (1996). Does Financial Development Cause Economic Growth? Time Series Evidence from 16 Countries. Journal of Development Economics, 51, 387-411. http://dx.doi.org/10.1016/S0304-3878(96)00421-X

Demetriades, P.O., \& Law, S.H (2006). Finance, Institutions and Economic Development. International Journal of Finance and Economics, 11, 245-260. http://dx.doi.org/10.1002/ijfe.296

Demirguc-Kunt, A., \& Levine , R (2008). Finance, Financial sector Policies and Long-Run Growth. Policy Research Working Paper, 4469 World Bank.

Enders, W (2004). Applied Econometric Time series. Hoboken:John Wiley and Sons.

Engle, R.F., \& Granger, C.W.J (1987). Co-integration and Error Correction: Representation, Estimation and Testing. Econometrica, 55, 251-276. http://dx.doi.org/10.2307/1913236

Estrada, G., Park, D., \& Ramayandi, A. (2010). Financial Development and Economic Growth in Developing Asia. ADB Working Paper Series No. 233, November

Goldsmith, R W. (1969). Financial Structure and Development. New Haven. CT: Yale University Press.

Greenwood, J., \& Jovanovic, B (1990). Financial Developments, Growth and the Distribution 
of Income. Journal of Political Economy, 98, 1076-1107. http://dx.doi.org/10.1086/261720

Gupta, K. (1984). Finance and Economic Growth in Developing Countries. Croom Helm, London.

Hadri, K. (2000). Testing for Stationarity in Heterogeneous Panel Data. Econometric Journal, 3, 148-61. http://dx.doi.org/10.1111/1368-423X.00043

Harris, R., \& Sollis, R (2003). Applied Time Series Modelling and Forecasting, London. John Wiley and Sons Publisher.

Honohan, P. (2004). "Financial Development, Growth and Poverty: How Close are the Links?", in C. Goodhart (ed.), Financial Development and Economic Growth: Explaining the Links, (38-65). London: Palgrave Macmillan

Im, k, Pesaran, H., \& Shin,Y(1997). "Testing for Unit roots in heterogeneous panels", DAE Working Paper No 9526, University of Cambridge

Johannes, T. A.; Njong, A. M., \& Cletus, N. (2011). Financial Development and Economic Growth in Cameroon, 1970 - 2005. Journal of Economics and International Finance, 3(6), $367-375$.

Joseph, A., Raffinot, M., \& Venet, B (1998). Approfondissement Financier et croissance: Analyses empiriques en Afrique Subsaharienne. Techniques Financiers and Developpment, Octobre, 17-25

Jung, W.S. (1986). Financial Development and Economic Growth: International evidence. Economic development and Cultural change, 34(2), 333-346. http://dx.doi.org/10.1086/451531

King, R.G., \& Levine, R. (1993). Finance and Growth: Schumpeter Might be Right. Quarterly Journal of Economics, 108, 717-737. http://dx.doi.org/10.2307/2118406

Kao, C. (1999). Spurious Regression and Residual-Based tests for Cointegration in Panel $\begin{array}{llll}\text { Data. Journal of } & \text { Econometrics, } & \text { 90, }\end{array}$ http://dx.doi.org/10.1016/S0304-4076(98)00023-2

Kose, M.A., Prasad, E. Rogoff, K., \& Wei, S-J. (2006). Financial Globalization: A Reappraisal. IMF Working Paper WP/06/189.

Larsson, R, Lyhagen, J., \& Lothgren, M. (2001). Likelihood-based Cointegration Tests in Heterogeneous Panels. Econometrics Journal, 4, 109-142. http://dx.doi.org/10.1111/1368-423X.00059

Levine, R. (2003). More on Finance and Growth: More Finance, More Growth? Federal Reserve Bank of St. Louis Review, 85(4), 31-46.

Levine, R (2004). Finance and Growth: Theory and Evidence. NBER Working Paper W10766 September. 
Levin, A, Lin, C., \& Chu, C (2002). Unit Root Tests in Panel Data: Asymptotic and Finite Sample Properties. Journal of Econometrics, 108, 1-24. http://dx.doi.org/10.1016/S0304-4076(01)00098-7

Lucas, R (1988). On the mechanics of Economic Development. Journal of Monetary Economics, 22, 3-42. http://dx.doi.org/10.1016/0304-3932(88)90168-7

Lucas, R (1990). Why doesn "t capital flow from rich to poor countries? American economic Review, Papers and Proceedings, 92-96.

Luintel, K.B, Khan, M, Arestis, P., \& Theodoris, K. (2008). Financial Structure and Economic Growth. Journal of Development Economics, 86, 181-200. http://dx.doi.org/10.1016/j.jdeveco.2007.11.006

Maddala, G.S., \& Wu, S (1999). A Comparative Study of Unit Root Tests with Panel Data. Econometric Review, 17, 57-84.

McKinnon, R.I. (1973). Money and Capital in Economic Development. Brookings Institution, Washington, DC.

Mckinnon, R I. (1991). The order of Economic Liberalization. Johns Hopkins University Press Baltimore

Meier, G. M., \& Seers, D. (1984). Pioneers in Development. New York: Oxford University Press.

Merton R C. (1987). A Simple Model of Capital Market Equilibrium with Incomplete $\begin{array}{llll}\text { Information. } \quad \text { Journal } & \text { Finance, 483-510. }\end{array}$ http://dx.doi.org/10.1111/j.1540-6261.1987.tb04565.x

Merton R C. (1995). A Functional Perspective of Financial intermediation. Financial Management, 24(2), 23-41. http://dx.doi.org/10.2307/3665532

Merton, R.C., \& Bodie, Z. (1995). "A conceptual framework for analysing the financial Environment” in Crane et al., (Eds), The Global Financial System: A Functional Perspective. Harvard.

Merton, R.C., \& Bodie, Z (2004). The Design of Financial systems: Towards a Synthesis of Function and Structure. National Bureau of Economic Research Working Paper No 10620.

Mishkin, F.S. (2007). "Globalization and Financial Development" Paper presented at the New Perspective on Financial Globalization Conference, International Monetary Fund, Washington DC, April 26.

Mobolaji, H I. (2008a). "Globalisation and Financial Development in SSA" A paper presented at the 13th Annual conference of African Econometric society, University of Pretoria, South Africa, July 2008

Odedokun, M O. (1996). Alternative Econometric Approaches for Analyzing the Role of the 
Financial sector in Economic Growth: Time series Evidence from LDCs. Journal of Development Economics, 50, 119-146. http://dx.doi.org/10.1016/0304-3878(96)00006-5

Patrick, H. (1966). Financial Development and Economic Growth in Underdeveloped Countries. Economic Development and Cultural Change, 14(2), 174-189. http://dx.doi.org/10.1086/450153

Pedroni, P (1999). Critical values for Cointegration Tests in Heterogenous Panels with Multiple Regressors. Oxford Bulletin of Economics and Statistics, 61, 653-70. http://dx.doi.org/10.1111/1468-0084.61.s1.14

Pesaran, M, H., Shin, Y., \& Smith R, J. (2000). Structural analysis of Vector error correction models with exogenous I(1) variables. Journal of Econometrics, 97, 293-343. http://dx.doi.org/10.1016/S0304-4076(99)00073-1

Rajan, R.G., \& Zingales, L. (2001). The Influence of the Financial Revolution on the Nature of Firms. American Economic Review, 91(2), 206-11. http://dx.doi.org/10.1257/aer.91.2.206

Rajan, R.G., \& Zingales, L. (2003). The Great Reversals: The Politics of Financial Development in the Twentieth Century. Journal of Financial Economics, 69, 5- 50. http://dx.doi.org/10.1016/S0304-405X(03)00125-9

Rioja, F., \& Valev, N (2004). Does One size Fit All? A Re-Examination of the Finance and Growth Relationship. Journal of Development Economics, 74, 429-447. http://dx.doi.org/10.1016/j.jdeveco.2003.06.006

Robinson, J. (1952). The Rate of Interest and other Essays. London: Macmillan.

Romer, P. (1986). Increasing Returns and Long-Run growth. Journal of Political Economy, 94, 1002-1038. http://dx.doi.org/10.1086/261420

Romer, P. (1989). Human Capital and Growth: theory and Evidence. NBER, Working Paper. 3173, Nov.

Romer, P, M. (1990). Human Capital and growth: theory and evidence. Carnegie-Rochester Conference Series on Public Policy, 32, 251-86. http://dx.doi.org/10.1016/0167-2231(90)90028-J

Saint-Marc, M. (1972). "La monetarisation, condition de la croissance en Afrique occidentale" in Tremblay, R, Afrique et integration monetaire, HRW Montreal Toronto, 109-130

Savvides, A. (1995). Economic Growth in Africa. World Development, 23(3), 449-458. http://dx.doi.org/10.1016/0305-750X(94)00130-Q

Schumpeter, J A. (1911). The Theory of Economic Development. Harvard University Press, Cambridge MA.

Spears, A. (1992). The Role of Financial Intermediation in Economic Growth in Sub-Saharan Africa. Canadian Journal of Development Studies, 13(3), 361-379. 
http://dx.doi.org/10.1080/02255189.1992.9669467

Venet, B., \& Hurlin, C. (2001). "Granger Causality Tests in Panel data Models with Fixed Coefficients” Working Paper Eurisco Universite paris dauphine, July Pp 1-31

Xu, Z. (2000). Financial Development, Investment and Growth. Economic Inquiry, 38, 331-344.

\section{Note}

Note 1. All other unit root tests indicate the variable is $I(1)$ when both specifications (using either the intercept alone or intercept and trend) except LLC that indicates the variable is I(2). Thus we consider it as an I(1) in line with IPS and Breitung tests.

\section{Copyright Disclaimer}

Copyright reserved by the author(s).

This article is an open-access article distributed under the terms and conditions of the Creative Commons Attribution license (http://creativecommons.org/licenses/by/3.0/). 